Article

\title{
Exile, Pistols, and Promised Lands: Ibsen and Israeli Modernist Writers
}

\author{
Irina Ruppo
}

Discipline of English, School of English and Creative Arts, National University of Ireland Galway, H91 TK33 Galway, Ireland; Irina.ruppo@nuigalway.ie

Received: 2 August 2019; Accepted: 12 September 2019; Published: 17 September 2019

check for updates

\begin{abstract}
Allusions to Henrik Ibsen's plays in the works of two prominent Israeli modernist writers, Amos Oz's autobiographical A Tale of Love and Darkness (2004) and David Grossman's The Zigzag Kid (1994) examined in the context of the Israeli reception of Ibsen in the 1950s and 1960s. To establish the variety of meanings Ibsen's plays had for the audiences of the Habimah production of Peer Gynt in 1952 and The Kameri production of Hedda Gabler in 1966, this article draws on newspaper reviews and actors' memoirs, as well as providing an analysis of Leah Goldberg's translation of Peer Gynt. It emerges that both authors enlisted Ibsen in their exploration of the myths surrounding the formation of Israeli nationhood and identity.
\end{abstract}

Keywords: Ibsen; Henrik; Oz; Amos; Grossman; David; Goldberg; Leah; modernism; Israel; Israeli literature; Peer Gynt; Hedda Gabler; translation; adaptation; Zionism

\section{Introduction}

The year is 1970, the setting is a Jerusalem school, and the dramatis personae are an irate teacher, the near-13-year-old Nonny Feuerberg, and Gabi, his beloved guardian and his father's secretary. Gabi demands that Nonny be given one more chance to stay in the school despite his 'limitations':

'What you may see as limitations, I happen to consider advantages!' She swelled larger in front of Mrs Marcus, like a cobra protecting her young. 'The advantages of an artistic soul ... Not all children fit neatly into the square framework this school provides, you see. Some kids are round, some are shaped like a figure eight, some like a triangle, and some'-her voice dropped dramatically as she raised her hand high in the style of that famous actress Lola Ciperola playing Nora in A Doll's House-'like a zigzag!'. (Grossman 1998, p. 88)

By mentioning Ibsen in his 1994 coming-of-age novel, the Israeli author David Grossman (b. 1956) makes the Norwegian playwright part of an elaborate fairy-tale quest, full of magic objects and daring escapes. The Zigzag Kid is about identity, Nonny's and his country's. On his zigzagging journey into his parents' past, Nonny mentally travels to Mandatory Palestine and to the early years of the State of Israel in the 1950s. He discovers that his grandparents are in fact the supposedly infamous robber Felix Glick and (the equally made-up) Lola Ciperola, a famous actor of Habimah Theatre, which is the national theatre of Israel. While the novel's portrayal of Habimah as a cornerstone of Nonny's identity tallies with Habimah's overall significance in Israeli cultural life, the mention of Ibsen, rather than an Israeli author, comes as a surprise. True, there were many Hebrew performances of plays by Ibsen, as well as other European classics, but these were often regarded as less significant than productions of original Hebrew plays (Rokem 1996, p. 68).

A similarly unexpected nod to Ibsen appears in another exploration of childhood and the beginnings of the Israeli state, namely the autobiographical A Tale of Love and Darkness (2005) by 
Grossman's older compatriot, Amos Oz (1939-2018). Recalling his late mother's 'strange and frightening stories', Oz compares himself to

Little Peer, the orphan son of Jon, the grandson of Rasmus Gynt [who] as he and his poor widowed mother Ase sat alone in their mountain cabin on those long windy, snowy nights [ ... ] absorbed and stored in his heart her mystical, half-crazed stories, about Soria-Moria Castle beyond the fjord, the snatching of the brides, the trolls in the hall of the mountain king and the green [daughters of the devil], ${ }^{1}$ the button moulder and the imps and nixies and also about the terrible Boyg. (Oz 2005, p. 261)

The passage is longer than the corresponding lines in Peer Gynt, and the comparison must have been important enough for $\mathrm{Oz}$ to use it twice, along with additional references to Peer Gynt (Oz mentions seeing the play on a shelf and hearing Grieg's suite).

Both of these prominent Israeli writers include Ibsen in narratives dealing with childhood, bereavement, and the years immediately before and after the foundation of the State of Israel. In this article, I take these mentions of Ibsen as invitations to read A Tale of Love and Darkness and The Zigzag $\mathrm{Kid}$ in the context of Ibsen's reception in Israel in the time of the setting of the crucial sections of the novels, 1950s and late 1960s, respectively, in so far as it can be reconstructed from press reviews, translation analyses, and performance analyses.

What I hope to uncover through this method is an insight into the nature of Ibsen's relation to Israeli literary modernism. ${ }^{2}$

\section{Background and Methods}

While the scope of this article is limited to two productions and one translation of Ibsen, it is worth mentioning that the Israeli and Hebrew-language receptions of Ibsen are complex and currently under-researched overlapping fields. Their complexity can be briefly glimpsed by considering Giuliano D'Amico's framework for a study of Ibsen's reception outside Norway. D'Amico suggests looking at six points, namely geography (the paths of Ibsen's arrival to a country); 'local, literary, theatrical and cultural traditions'; translators, theatre directors, and other 'middlemen' who promoted Ibsen in the receiving country; the relationship between the book market and the performance history; the issue of copyright (which is an important factor when analyzing reception during Ibsen's life-time and does not apply in this case); and, finally, translations (D'Amico 2014). In a pattern which differs from the maps of Ibsen's gradual ingress into local cultures in various European countries, Ibsen entered via multiple channels as part of several ingredients that made up the melting pot of Israeli society. Jewish immigrants from Germany, Russia, France and multiple other European countries counted Ibsen as part of their cultural heritage. Reviews of Israeli productions of Peer Gynt referred to past European productions. At the same time, the Hebrew Ibsen, both in book form and in the theatre, predates the foundation of the State of Israel. Hebrew-language translations of Ibsen's plays were relatively popular in Mandatory Palestine, with the first production being An Enemy of the People in 1905 (Rokem 1996). The playwright's name appeared in several early twentieth-century Hebrew-language periodicals published in Europe. Ibsen's plays became part of the repertoire of several important theatre companies, such as Habimah and the Kameri. Thus, while his plays were widely translated into Hebrew, often by prominent writers and poets who were commissioned to produce a version for a new production, these translations were not the first source of the public exposure to Ibsen. This situation was not static, however. As Israeli society

1 The translation reads 'ghouls', which is not true to Ibsen's play or Oz's Hebrew text, which reads 'bnot-ha-shed', which means daughters of the devil.

2 I wish to acknowledge the support of the NUIG College of Arts, Social Sciences, and Celtic Studies Research Support Scheme. My thanks also go to the staff of the Israeli Center for the Documentation of the Performing Arts and to Gabriel Lanyi and Ciaran McDonough for their comments on the early version of the article. 
continued to develop, Hebrew-language texts and local productions, which included performances of Ibsen in Arabic, became more important than memories of European productions.

A further complexity has to do with the method adopted here. In line with my previous work on the reception of Ibsen in early twentieth-century Ireland (Ruppo Malone 2010), I propose a seventh area to add to D'Amico's six areas of interest, namely literary responses to Ibsen's work. As the case of the Irish Revival shows, Ibsen's influence on local literature can be far greater than the public exposure to his work. In Ireland, there were very few Ibsen productions, yet several prominent writers, including Yeats and Joyce, read Ibsen, reviewed his plays, responded to them in imaginative ways that transcended mere imitation, and engaged with lesser known and less immediately accessible aspects of his work. The two strands of reception, the literary, and the public, however different they may seem, are not separate. Yeats and Joyce in Ireland and Oz and Grossman in Israel, are part of the same 'interpretive community', to use Stanley Fish's phrase (Fish 1980), as journalists, actors, and members of the public. Their responses may be more imaginative, and may take more time to gestate, but writers too are members of the public. Writers too are readers.

Here, however, another factor should be taken into account, namely, the separation of the text from its author. After Barthes, literary texts cannot be seen as mere expressions of their authors' wishes; a text is not 'a line of words releasing a single "theological" meaning ... but a multi-dimensional space in which a variety of writings, none of them original, blend and clash' (Barthes 2013, p. 315). I would therefore like to refine my point. Not only writers, but also the texts that they produce are equal members of their interpretive communities. Oz's and Grossman's novels are spaces within which other texts, such as Ibsen's plays, are read and re-interpreted

The approach that I adopt here is intertextual in the sense outlined by Gregory Machacek in his study of allusion: texts are examined 'synchronically, in connection with a contemporaneous semiotic field made up of literary and nonliterary texts' (Machacek 2007, p. 524). Adding the literary dimension to the study of an author's reception does not turn it into a source hunt or a guess-game regarding the authorial intention. Rather, it allows one to enter a complex network of readership, in which each text in its response to Ibsen, be it a literary allusion, a review, or an actor's memoir, echoes other responses. New meanings assigned to the new author's work in the receiving country thus grow through reflecting each other.

In this article, I analyze an array of echoing responses to Ibsen that connect Oz's and Grossman's novels to the time of their setting, the 1950s and late 1960s, respectively. The concerns and tensions expressed in Leah Goldberg's 1952 translation of Peer Gynt reverberate in some of the responses to the production of the play. They also echo Oz's parents' responses to immigration and folklore, as described in A Tale of Love and Darkness, and help us understand the range of meanings hidden in the allusions to Ibsen in that work. Likewise, reviews of the contemporary Israeli productions of $A$ Doll's House and Hedda Gabler are examined alongside an analysis of the story of Zohara, which, I argue, is The Zigzag Kid's response to Hedda Gabler. Throughout the article, I use the words 'play' and 'game' when referring to the authors' and translator's engagements with Ibsen as well as their responses to the ideological trends of the time, a subject that I focus on in the concluding part of the argument. I do not attempt to formally relate the patterns of literary engagement to the patterns one sees in gaming (though this approach has been adopted by John K. Hale who used Roger Caillois' theories on games to discuss Milton's allusions to Ovid (Hale 1989). I use these terms because 'games' and 'playing' are appropriate words to describe a process that is both conscious and subconscious and that presupposes, as in the intertextual approach to the study of text, a kind of equality between the participants in the game, be they human beings or texts.

\section{Amos Oz and Peer Gynt in Habimah 1952}

A Tale of Love and Darkness tells the interrelated stories of Oz's childhood in the 1940s and 1950s and the experiences of his family and other Eastern European Jewish immigrants during the years before and immediately after the foundation of the State of Israel in 1948. Apart from documenting life in 
Jerusalem, the novel also ventures into Oz's parents' and grandparents' past, describing their life in Europe, especially the mother's life in the Ukranian town of Rovno. The suicide of Oz's mother, Fania Klausner, in January 1952, is central to this work, which is part memoir and part novel (Mendelson-Maoz 2010, p. 83). It is mentioned at its start and it ends it, functioning as both the framing device of the work and its core mystery. The allusions to Peer Gynt occur in relation to Fania Klausner. It is obvious that by describing himself as Peer and his mother as Åse, Oz underscores his mother's influence on his development as a writer. I propose that these allusions have another dimension that becomes apparent when Oz's engagement with Ibsen is contextualized within other contemporary responses to Peer Gynt.

By contemporary responses, I do not mean contemporaneous with the publication of the novel, but rather with the time in which the novel is set. The play premiered in Israel in May 1952, just a few months after Fania Klausner's suicide and a few months before the young Amos changed his name from Klausner to $\mathrm{Oz}$ and left Jerusalem for a kibbutz. Peer Gynt at the Habimah was an important occasion in the Israeli theatre; it was extensively reviewed and debated in the press. The translation of the play into Hebrew was commissioned from the renowned Israeli poet Leah Goldberg. It was published in the following year. In fact, $\mathrm{Oz}$ refers to that volume when he describes the bookshelves in the kibbutz residence of his lover Orna (Oz 2005, p. 476). That is to say that Peer Gynt, in 1952-1953, was a work of some importance in Israeli literary culture.

\subsection{Leah Goldberg's Translation}

In the introduction to her Hebrew version of the play, the Lithuanian-born poet Leah Goldberg explains that she used Christian Morgenstern's German translation (1867), the Russian translation by Anna and Peter Hansen (1907) and the English translation by Robert Farquharson-Sharp (1897). She also thanks the Swedish director of the play, Sandro Malmquist, for giving her further insights into the text of Peer Gynt whose original language she could not access. Goldberg's rhyming translation echoes Ibsen's rhythms and is generally faithful to the original. There are some intriguing deviations, however. For example, while Goldberg uses the terms 'troll' and 'boyg' throughout the text, other supernatural entities are called by their Hebrew equivalents. During his fight with the mysterious Boyg, Peer exclaims:

Var her bare en nisse, som kunde mig prikke!

Var her bare så meget, som et årsgammelt trold!

(Ibsen 1867, p. 57)

Were there only a nixie here that could prick me!

Were there only as much as a year-old troll!

(William and Archer 1909, p. 86) ${ }^{3}$

In Hebrew the 'year-old troll' is a 'son of a troll', but the 'nisse' or 'nixie' is gamad ben-bliya'al (Goldberg 1953, p. 80). Gamad means dwarf, while ben-bliya'al denotes an evil or wicked person, or indeed the son of a devil. The term brings Peer Gynt into the proximity of the Kabballah, Rabbinical texts, and Jewish folklore.

Mother Åse blames her fairy tales for Peer's reckless behaviour; she believes he has over-identified with stories about 'prinser og trolde og alleslags dyr' (Ibsen 1867, p. 38) ['princes and trolls and all sorts of beasts' (William and Archer 1909, p. 55)]. Goldberg translates this as 'shedim ve ruhot ve mlakhim adirim' (52). 'Shedim ve ruhot' [ghosts and spirits] are the names used in Rabbinical literature, ${ }^{4}$ and 'great kings' resonates of the Bible. Even more striking is the use of words such as shabbat (Sabbath)

3 As William Archer's translation is far more faithful to the original than that of Farquharson-Sharp, I will use it here when a simple sense of the original is required.

4 http://jewishencyclopedia.com/articles/13523-shedim. 
and torah (the Pentateuch). When Peer Gynt meets the Troll King's daughter ${ }^{5}$ and boasts about his supposed riches, instead of talking about his Sunday clothes, he refers to his 'bigdey-ha-shabat', Saturday clothes (Goldberg 1953, p. 63), the play's Christian setting notwithstanding.

The boundaries between Christianity and Judaism are similarly flouted in the final act. In the eulogy of the man who cut off his finger to avoid the draft (which Peer overhears upon his return to Norway), the pastor mentions that the man sent his children to school as it was time for them 'lilmod tora' ('to learn the Torah') (Goldberg 1953, p. 209), which is an expression unequivocally related to the traditional cheder, a Jewish religious school for young children. Goldberg does not change the setting of the play; she does not turn its pastors into rabbis. Nor does Goldberg's use of Judaic terms constitute a mere domesticating of Ibsen. Rather, Goldberg expands the use of the Jewish terms to make them larger linguistic containers; she allows these terms to pertain to more religions and cultures than just Judaism. Subverting the established European paradigms in which various Christian denominations were dominant while Judaism was a marginalized and persecuted religion, Goldberg turns Hebrew and Judaism into tools for depicting other cultural experiences.

Other deviations from the original evoke specifically Zionist expressions. In Act 4, Peer daydreams about digging a canal in the North-African desert and founding a new country peopled with his offspring and named 'Gyntiana'. In Goldberg's translation, his Gyntiana is a 'young country', 'madina tzaira' (Goldberg 1953, p. 143). While this is a literal translation of Ibsen's phrase 'mitt unge land' (Ibsen 1867, p. 95), it is also a frequently used term to refer to the state of Israel. Another even more blatant use of Zionist terminology is found in the already mentioned eulogy of the draft dodger. We are told that 'one spring the torrent washed it all away/their lives were spared. Ruined and stripped of all/he set to work to make another clearing' (William and Archer 1909, p. 216). ${ }^{6}$ In Hebrew, the situation is more complicated: 'aviv ehad hanahal migdotav/ yatza. haam zanah et nahluto /akh hu hazar kekodem el sdotav'. In the following literal translation of the text, the words with several possible meanings are shown using forward slashes:

One spring, the river burst its banks.

The nation/people left/abandoned its property/inheritance/heritage,

But he came back as before to his fields. ${ }^{7}$

The use of the word ' $a m^{\prime}$ ' [nation, folk, people] in the second line and 'nahala' (property/heritage) in conjunction with the loaded phrase 'as before' (that in Hebrew is related to the word 'ancient') are redolent of the Zionist discourse. They paint the picture of a land which was abandoned by its people and to which the hero returns in fulfilment of an ancient destiny. Neither the Russian nor the German translation have anything comparable. Goldberg seems to draw a linguistic parallel between the man and the halutzim. The halutzim, or pioneers, were Jews from Eastern Europe who settled in Mandatory Palestine in the wake of the Balfour Declaration of 1917, which indicated British support for 'the establishment in Palestine of a national home for the Jewish people' (Fromkin 1989, p. 297). Trained in agriculture, they came with the intention to cultivate the land. They were celebrated in school textbooks and depicted, similarly to the man in the sermon, as hard-working courageous people who built new cities in an unforgiving climate. Strangely, Goldberg conflates their image with that of a draft-dodger, a figure that would have been anathema to the Zionists of the 1950s who idealized the army.

5 The title 'Troll King' is not in the original, where this character is referred to as 'Dovregubben', the old man of the Dovre. I am using this term, which appears in several translations, for the sake of convenience.

6 Archer's translation is very close to the original, which reads ‘En Vaar blev alting revet bort af Flommen. De slap derfra med Livet. Arm og nøgen han tog paa Ryddningsværket fatt paany' (Ibsen 1867, p. 137). The meaning of Farquharson-Sharp's version is the same as Archer's.

7 All translations of Leah Goldberg's text, the newspaper reviews of Israeli productions of Ibsen's plays, and Shimon Finkel's memoir are my own. 
The game that Goldberg plays with Ibsen and Zionism is not surprising if we note Adriana Jacobs' observation that for the poet, translation did not only serve the national canon, but also 'mediated relations between the immigrant diasporic world and the emerging Jewish national culture in Palestine' (Jacobs 2014, p. 480). Jacobs argues that in her translations, Goldberg 'created sites of resistance and polyphony in an increasingly hegemonic and monolingual national context, while simultaneously inscribing their Hebrew writing in more international, multilingual, and heterogeneous mappings of poetic influence and tradition' (Jacobs 2014, p. 480).

Ibsen's trolls are meant to parody nationalism. In Goldberg's translation, this is taken one step further; her trolls might have reminded the public of the ideological imperative to buy only locally made goods. Oz, in A Tale of Love and Darkness, describes this practice as follows: 'We had an iron rule that one should never buy anything imported, anything foreign' (Oz 2005, p. 17). The phrase used by $\mathrm{Oz}$, 'totzeret hutz', is almost the same as the phrase used by Goldberg's trolls: 'tozteret shel eretz aheret'. Goldberg, moreover, makes the trolls far more sinister in their contempt for imported goods than Ibsen. Archer's translation, which is close to the original as well as to the German ${ }^{8}$ and the Russian ${ }^{9}$, goes as follows: 'to our Dovre's renown:/Here all things are mountain-made, nought's from the dale/Except the silk now at the end of your tail' (William and Archer 1909, p. 73). Goldberg's translation reads: 'Kan bedovre—veze hesegeynu harav/kol totzeret shel eretz aheret taharam/hutz miseret hameshi biktze hazanav' (Here in Dovre-and this is our great achievement/Any produce of another land will be confiscated'/Except for the silk bow at the end of the tail) (1953, p. 68).

An even more striking response to contemporary ideology is the following deviation from the original, also found in the scene where Peer nearly agrees to marry the Troll King's daughter. The Troll King's conditions are as follows:

For det første maa du love, at du aldrig ændser

hvad der ligger udenfor Rondernes Grænser;

Dag skal du sky, og Daad og hver lysbar Plett.

Peer Gynt must 'never give heed/ To aught that lies outside the Ronde hills' bounds;/ Day you must shun, and deeds, and each sunlit spot' (William and Archer 1909, p. 70). In English, German and Russian ${ }^{10}$, the emphasis is as in the original: on 'not giving heed' and on shunning sunlit places. In Hebrew, by contrast, the emphasis is on Peer's physical confinement in the land of the trolls. There is a sense of claustrophobia about the old troll's conditions as they appear in Hebrew:

Lo titze haim min haeretz hazot

Vetihye shouatkha neemenet aleynu

Lo titze leolam et goulot artzeynu

Vetihye rak beyn elu hagiv'ot

(You shall never leave this country

And your oath shall be loyal to us

You shall never leave the borders of our country

And you shall only abide between those hills.)

8 Sodann mußt Du Deine Christentracht abwerfen; Denn dies laß zu Dovres Ehren Dir einschärfen: Hier ist nichts von jenseits der Felsenscheide, Außer hinten am Wedel die Schleife von Seide. (Christian 1907 http://gutenberg.spiegel.de/buch/peergynt-1716/1)

9 K чести будь сказано нашей, у нас, Все своего производства; Все, что мы носим, сработано здесь, В скалах родных; из долины, Банты лишь те, что у нас на хвостах(Anna and Hansen 1956, p. 451).

10 Прежде всего обещаешь, Плюнуть на все, что вне Рондских границ, Света и дня сторониться, Светлого дела и солнца луча. (Anna and Hansen 1956, p. 450). 
Unlike the translators she consulted, Goldberg dispenses with the word 'Ronde' and instead has the Troll King refer to the place simply as 'this country' (haaretz hazot) and 'our country' (artzeiynu), which are both words commonly used in Modern Hebrew to refer to Israel (66).

The implication of this move is shocking. Is it possible that Goldberg, who had shunned political writing throughout her life, chose the subtle medium of translation to criticize Zionism? While this possibility cannot be ruled out, I suspect that the intended subtext of Goldberg's deviations from Ibsen's original is more complex than criticism of the ruling ideology of Goldberg's newly established state. Goldberg is critical not of Zionism per se, but of the all-prevalent demand that the new immigrants negate their roots and let go of memories of Europe, their European culture, and even their Jewish-European identity. Shlilat hagalut, the rejection of exile, was a central tenet of Goldberg's contemporaries, and this demand was, for her, a source of tension. As Jacobs explains, Goldberg 'was acutely aware of how a "rejection of exile" conflicted with her ... engagements and dialogues with European literary cultures' (Jacobs 2014, p. 481). The imperative to reject the past possibly also made it harder, not easier, for the Jewish immigrants to accept the new country as their home.

When domesticating Ibsen, Goldberg made his play reflect not only the language, but also the tensions within her society. The Hebrew Peer Gynt is a carnival site where familiar ideals, such as fatherland, inheritance, Judaism, and Zionism, can be re-encountered, and re-examined in a new light. Through its encounter with Ibsen, Hebrew becomes more international than it had ever been; it becomes possible to speak of Sunday clothes as Sabbath clothes, and of Israel as a not just a place of refuge, but also as a place of confinement and exile.

\subsection{Sandro Malmquist's Israeli Peer Gynt}

While Goldberg's translation displayed both daring and subtlety in domesticating Ibsen, the performance was motivated by different factors. In the early 1950s, the management of Habimah decided to gain new experience, expand its repertoire and preserve its reputation as the national theatre through a series of productions by invited directors from abroad (Rokem 2011, p. 133). The Swedish Sandro Malmquist became a frequent guest, directing John Gabriel Borkman in 1953 and The Wild Duck in 1954 .

Malmquist is remembered by Nava Shean, who played the Troll's Daughter, as having a great love for 'everything in Israel, from yogurt to the incomprehensible Hebrew language' and for communicating in broken English, and mostly through the medium of pictures (Shean 2010, p. 84). His approach to Peer Gynt seems to have been similar to that of Hans Jacob Nilsen, who declared, in 1948, that 'Peer Gynt is no journey through Norway: it is a journey through a human mind' (Marker and Marker 1989, p. 25). Shean recalls that Malmquist's stationary constructivist stage set, around which Peer moved in spirals as if circling around his self, was meant to 'make clear that the play had nothing to do with a real-life journey from one scenery to another, but with mental drama taking place within one man's soul' (Shean 2010, p. 85). His use of projections, however, created a memorable visual spectacle, which was praised precisely for its ability to recreate various landscapes. Apparently, 'the stage resembled a huge [living and moving] painting, taken from an album of Northern painters' (Eshel 1952).

In fact, Malmquist's anti-romantic vision was partly sabotaged: he had hoped to avoid using Grieg's score, but the horrified cast of Habima protested: 'Our audience can recognize Grieg's music, like 'Solveig's Song', and will not be prepared to accept the play with any other music' (Shean 2010, p. 85). Malmquist was on the verge of leaving, but eventually conceded the point. Shimon Finkel, who played Peer, also recalls arguing with Malmquist. Finkel agreed that the performance needed to transcend the stagy romanticism of early twentieth-century productions, such as the one he had seen in the Royal Theatre, Berlin, in 1922. He admired Malmquist's choreography. However, he disliked the scene with the Boyg and tried to convince the director to remove it, though on this matter, Mamlquist would not be budged. Finkel was impatient to get through what he called 'philosophical' scenes of Act 5 ; he recalls playing them with 'excessive irritation, wishing to ... get to the last scene with Solveig, which gave [him] the opportunity to express one of the most heartfelt and dramatic moments in the 
play' (Finkel 1971, p. 151). Peer's reunion with Solveig, the tragedy of Åse's death, and the bathos of the Anitra scenes (which drew a lot of laughter from the audience) were key points for Finkel, making up for the 'philosophy' and other 'incomprehensible scenes' (Finkel 1971, p. 151).

While Finkel's romanticism was at odds with Malmquist's vision, it was more in line with what the public wanted to see. The use of Grieg's music was indeed complimented. In fact, the extensive reviews focused less on the production than on the supposed meaning of the play and the significance of its performance in Israel. The reviews, as Freddie Rokem observes, focused less on the director's vision than on the idea of nationhood and on 'the ideology of the State of Israel and its concern for returning the Jews to their ancient homeland' (Rokem 2011, p. 35). Malmquist's attempt to contemporize the play by dressing Begriffenfeldt as Hitler attracted only negative comments (Eshel 1952). His exploration of the gradual bestiality of Peer's 'erotic imagination', conveyed through the costume of the Troll's daughter featuring two sets of breasts (Shean 2010, p. 86), was barely mentioned in the reviews. The detail was only picked up in the satirical review by Ephraim Kishon written from the perspective of a recent immigrant from Hungary. The play is recounted in a series of jokes about Peer being pursued by 'giant dwarves' in Act 2, carrying a boat with 'businessmen from Beersheba' in Act 4, getting arrested by Hitler for 'speaking Yiddish wheareas one can also speak Hebrew' and 'preaching Zionism to the masses' in Act 5 (Kishon 1952). His comical approach notwithstanding, Kishon was similar to the rest of the critics in focusing his review on Israeli life rather than the play.

Indeed, the reviewer of the centrist Haboker claimed that 'one can learn from the play a national message of our own':

Peer Gynt goes around the whole world, and, in the end, he comes to Norway full of disappointments-and there: his first love is loyal to him. Can it not be a wonderful parable for our return to Zion? I always say that the theatre does not show anything Zionist or national, and here I see that there are no borders in the world of the spirit. (Unsigned 1952)

By contrast, Sh. Israel, in the extreme nationalist Sulam thought, the play was about 'the cancer of individualism from which the Jewish people could be freed' and that it embodied 'Europe that spat us out and that deserves to be expelled ... from our souls' (Israel 1952). 'Sh. Israel' is likely to have been a pseudonym of the paper's editor, Israel Eldad (also known as Scheib). He was a former member of the paramilitary group Lehi and an advocate of the establishment of a sovereign Jewish kingdom within the biblical borders. This extremist reaction contrasts with the review by A. Aisenberg, who proposed a connection between Peer's self-deception and 'our life in our young country'. 'How many among us', wondered Aisenberg, 'dreamed dreams of worlds a plenty when they were young and saw themselves as their centre ... and on facing the grey reality ... were swept in the whirlpool of egoism'. For Aisenberg, the connection between Peer Gynt and Israel was in Peer's inability to settle down. 'One of the problems of the current crisis', he wrote 'is ... the lack of ideals ... half of the population of the country do not, at the moment, feel rooted in the places where they live. And has an educational atmosphere been created to stop people wandering within the country and outside its borders? Aren't the young people dreaming of leaving the country that was won by the blood of their fathers?' (Aisenberg 1952).

\subsection{Peer Gynt and the Lost Promised Lands}

What these reviews suggest is that Peer Gynt struck a chord with members of the audience whose own life-paths, as citizens of the newly established State of Israel, reflected the disappointments and frustrations of Ibsen's protagonist. In Ibsen's counter-romantic drama (Durbach 1982, p. 6), Peer's ambitious belief in the power of the self to transcend reality and fashion its own paradise is given expression in his tales of the Soria Moria castle and a folkloric land of his dreams where he is emperor. This belief is then subverted in the final act when 'with the eyes of a dying Moses, Peer gazes on a Promised Land which his own experience has turned to dust and ashes' (Durbach 1982, p. 9). 
Frustrated dreams of a promised land is one of the major themes of A Tale of Love and Darkness. This sense of disappointment refers to both politics and the everyday. Oz describes his elderly relatives' unfulfilled hopes that as Jews in their own state, they would 'treat our Arab minority justly fairly, generously, ... shar[ing] our homeland with them, shar[ing] everything with them' (Oz 2005, p. 185). Oz also describes his parents' unhappiness in Jerusalem. He recalls his parents singing Zionist songs about 'the land where 'all our hopes will be fulfilled'. 'But what were their hopes', Oz asks; 'Perhaps they ... thought they would find in the ... Land of Israel something less ... crudely materialistic and more idealistic; something less feverish and voluble and more settled and reserved' (Oz 2005, p. 242). This experience of Israel not as a promised land but as a place of exile is the sentiment voiced, as we have seen, in Goldberg's translation of the Troll King's admonitory words to Peer Gynt. While their viewpoints were different, in reviewing the play, many critics engaged with what $\mathrm{Oz}$ calls 'Worldatlarge', 'attractive, marvellous, but to us ... dangerous and threatening' (Oz 2005, p. 4). Similarly, Grossman in See Under: Love calls Europe 'Over There', a place you weren't supposed to talk about too much, only think about it in your heart and sigh with a drawn-out krechts, oyyyy, the way they always do' (Grossman 1991, p. 13). Oz explains that 'Europe ... was a forbidden promised land, a yearned-for-landscape of belfries ... forests and snow-covered meadows'. Here, Oz mentions the very same words that Goldberg uses in Peer Gynt, 'meadow' (ahu), 'hut' (bikta), saying that they had a 'sensual aroma of a genuine, cosy world, far from the dusty tin roofs, the urban wasteland of scrap iron and thistles ... of our Jerusalem' (2).

The uneasy relationship with Europe can be sensed behind another reviewer's assertions that Norwegian folklore was alien to the Israeli audience of Peer Gynt:

What do we care about St Peter that guards the heaven's gates. What do we care about trolls and ghosts from northern fairy tales. They can only provoke our curiosity; we do not identify with them; the strings of our times are not tuned for that. (Zusman 1952)

This sentiment seems to clash with Grossman's and Oz's assessment of their society's relationship with Europe. It contrasts, moreover, with Goldberg's decision to domesticate Ibsen through the use of Hebrew and Jewish equivalents for various folkloric and Christian terms in the play. Oddly, this reviewer, whose name, Zusman, suggests that he was a European Jew, describes the folklore of a Northern-European country as an alien territory. Yet, there is a sense of protesting too much; this is a forced negation rather than a factual assessment. The phrases 'what do we care' and 'our times' are appeals to the readers' nationalism and modernity. What is dismissed is not only Europe, but also folklore in general. Indeed, folklore was a controversial subject in these years.

While folklore was an important aspect of the European-Jewish experience, as reflected in the works of prominent Jewish writers such as S. An-sky (1863-1920) and, later, Isaac Bashevis Singer (1902-1991), the preservation of Jewish folklore was often criticized in the early days of Zionism. Preserving folklore meant keeping aspects of Jewish identity that Zionists wished to discard (Rubin 2005). Oz explains that his father's disregard for his mother's stories stemmed from his typically Zionist contempt for anything insubstantial and sentimental:

Like so many Zionist Jews of our time, my father ... was embarrassed by the shtetl and everything in it ... He wanted us all to be born anew, as blond-haired, muscular, sun-tanned, Hebrew Europeans, instead of Jewish Eastern Europeans ... He considered the supernatural to be the domain of charlatans and tricksters. He thought the tales of the Hasidim to be mere folklore, a word which he always pronounced with ... loathing'. (Oz 2005, pp. 35-36)

For Oz's father, his wife's Åse-like stories embodied aspects of Jewish identity and Jewish stereotypes that he rejected. Instead, in the figure of the sun-tanned Hebrew-European, he idealized stoicism, hard work, and pragmatism. The fear of folklore as something sentimental and weak is also noticeable in Goldberg's introduction to Peer Gynt. Goldberg defends Ibsen and explains that his use of folklore does not stem 'from romantic sentimentality or simmering admiration for the far away ... [but from] the inner rage of one who understands the link between the barren and rocky land of 
an impoverished nation and their fairy tales' (Goldberg 1953, p. 9). Here too, stoicism is contrasted positively with sentimentality.

These objections to folklore and Europe suggest that Oz's decision to cast himself and his mother in the roles of Peer Gynt and Åse was an expression of an identity crisis within his society and family. It should be noted, moreover, that the 'negation of exile' and the concurrent negation of Europe, aspects of Jewish identity, and folklore at large were not mere reflections of Zionist aspirations. It was also a strategy adopted by many European Jews in Israel as a response to the trauma of the Holocaust. The entire Jewish populations of the Eastern European hometowns of Oz's mother and Leah Goldberg were murdered. As Grossman describes in See Under: Love, this was something the survivors tried not to speak about.

In an analysis of $A$ Tale of Love and Darkness as an immigration narrative, Adia Mendelson-Maoz shows how the novel operates within the tension between the utopian narrative of the Zionist project and the reality of the Jewish immigration experience. Mendelson-Maoz explains that it 'reveals the trauma of immigration, exposing, alienation, death, and the failure of his parents' generation to blend it. It describes the violence inherent in the Zionist project that undermines the hegemonic ideology' (Mendelson-Maoz 2010, p. 78). This subject, she argues, is served well by the style of the book, which presents a non-linear vision of history and a literary vision of autobiography. Ibsen, it appears, has a part to play in Oz's modernist revision of trauma in personal and national history. Ibsen's Norway, or rather the land of Peer Gynt's imagination, becomes a site where the contradictions between loss, trauma, longing, and fear can be reconciled, and the stories of the Ukrainian and Lithuanian forests and meadows of Oz's mother and Leah Goldberg could find a home. Ibsen's self-exploratory study of inauthenticity becomes a way for $\mathrm{Oz}$ to anchor his own experience of inherited exile, grief, and frustrated Zionism.

\section{Grossman and the Imaginary Ibsen Performance}

In Grossman's The Zigzag Kid, set in 1970, Ibsen also figures as an emissary from 'Over There'. When Nonny's guardian, Gabi, 'raise[s] her hand high in the style of that famous actress Lola Ciperola playing Nora in A Doll's House' (Grossman 1998, p. 88), she partakes in a series of actions that gesture towards the world beyond Israel. These include Nonny's father's purchase of an old Humber, Felix Glick's hijacking a train and escaping in a Bugatti, Gabi's recital of Lorca, and Nonny's ill-fated attempt to become 'the first Israeli matador' (Grossman 1998, p. 124) by attacking his neighbour's cow. These are all expressions of longing for a glamorous world beyond the Israeli reality. Through several plot twists, Nonny's attitude to this reality changes.

In the first pages of the book, Nonny is riding a train, supposedly to visit his boring uncle in Haifa. Then he discovers that he is in for a birthday surprise, which turns into a fabulous adventure, which turns into a kidnapping, which also proves to be an illusion. The infamous criminal Felix Glick and the famous actor Lola Ciperola are in fact Nonny's grandparents; from them, he hears for the first time the story of his mother who died at the age of twenty-six. This is a novel about surmounting the routine of loss and grief and discovering the excitement that lies beyond. The question is what was the Ibsen production at Habimah in which Nonny and Gabi saw Lola Ciperola? To solve this riddle, some zigzagging is required.

A Doll's House was first staged in 1921, which falls outside the time frame of the novel. It was then staged in 1959, but not in Habimah, but the Kameri, its well-established rival, also based in Tel Aviv. In fact, even though several Ibsen productions were mounted in Habimah, A Doll's House was not one of them. The Habimah first lady, Hannah Rovina (1888-1980), played Mrs Alving in Ghosts in 1947 , but never Nora. Besides, in 1970, she would have been too advanced in years to be the prototype for Nonny's youthful grandmother. Hannah Maron (1923-2014) who played Nora in 1959 is a more likely candidate. Of course, this production is also too early to be remembered by the thirteen-year-old Nonny, but Maron also played Hedda Gabler in 1966. She was often called the 'queen' or 'the first lady of the Israeli theatre' whose every absence from the stage was noted, and whose come-backs 
in A Doll's House, after an absence of a year, and in Hedda Gabler, after two years, were celebrated in the press (Bar-Kadma 1966). Several details, such as her reputed fiery temperand her proclivity for grand roles point to her as the possible model. A telling detail is that Hannah Maron's son's name was Amnon, which is also Nonny's full name. Yet, Maron played in Ibsen's productions in the Kameri, not Habimah. The author avoids pointing to a real production or a real actress while zigzagging just close to the actual events. In fact, A Doll's House and Hedda Gabler are both absorbed by the novel's exploration of theatricality. However, Hedda Gabler, though unmentioned, is more important.

The significance of $A$ Doll's House for the novel emerges in relation to Toril Moi's point on how the play exposes the characters' interactions with each other as a series of 'self-theatricalizing fantasies' (Moi 2006, p. 234). Moi argues that 'Ibsen's modernism', in A Doll's House, is based on the sense that we need theatre ... to reveal the games of concealment and theatricalization in which we inevitably engage in everyday life' (Moi 2006, p. 241). The improbable plot of The Zigzag Kid, with its pretend kidnappings that turn out to be real, only to be revealed as family outings, articulates precisely that aspect of human relationships. The love stories of Lola and Felix and of Nonny's father and his mother are both highly theatrical. Even more importantly, they become part of an elaborate game that Gabi plays in a bid to win Nonny's father's heart. At the end of the novel, Nonny wonders whether, in fact, the whole elaborate adventure has been orchestrated by Gabi, and whether, in fact, he has been used as an actor in her play. Whatever the case may be, Gabi, even as she embraces the man who has finally proposed to her, does not forget Nonny; returning him to the role of the all-seeing spectator, she reaches for Nonny's hand to pass a secret message of gratitude and relief: 'At last' (Grossman 1998, p. 308). The novel positions itself in the shadowy zone between reality and mimesis. It is theatre that comes dangerously close to reality only to become theatre again. If A Doll's House explores theatricality predominantly in the sphere of human relations, Hedda Gabler deals precisely with this cross-over from fantasy into tragedy through the figure of its eponymous heroine whose character may be seen as a prototype for Nonny's mother, Zohara.

Zohara is a dreamy and troubled child who grows into a woman closely resembling Hedda. Consider the following statements: 'Your mother was very strong woman [sic] ... and very beautiful. She was strong like only very beautiful people are (93); 'Beautiful, wild like a tiger ... she was the queen of Tel Aviv' (226); 'She was even ... cruel ... There are some whose lives were ruined because of her ... cruel like a kitten playing with mouse' (227); 'how she galloped on horseback, she would fly' (95). Readers familiar with Ibsen's play should be able to recognize Hedda in Grossman's image which conflates beauty, cruelty, and power. Hedda flouts nineteenth-century conventions; she offends an elderly lady, threatens to burn another woman's hair, destroys a manuscript, and hopes to convince a man to commit suicide because this action would give her 'a sense of freedom to know that a deed of courage is still possible in this world,-a deed of spontaneous beauty' (Edmund and Archer 1911, p. 210). Like Zohara, Hedda is a skilled rider; she is 'General Gabler's daughter', still remembered even after her marriage for 'riding down the road [ ... ] In that long black habit—and with feathers in her hat' (Edmund and Archer 1911, p. 24).

Of course, Hedda is also an accomplished shot who fires the pistols that she has inherited from her father to cure the devastating boredom of her marriage. A weapon also shows up in The Zigzag Kid. The first in a series of unusual items, which the novel treats like fairy-tale artefacts or theatrical props, is a nineteenth-century woman's pistol held by Felix Glick as he highjacks the train. In an inversion of the situation in Hedda Gabler, it is the father who inherits the daughter's pistol. Glick uses it to threaten the driver of the train, tells the shocked Nonny that it is only a toy, and then causes him even more distress by firing the pistol. This business with the pistol encapsulates both the play's and the novel's preoccupation with the border lines between a beautiful gesture and gruesome violence. Their cruelty, 'Amazon tastes for horses and weapons' (Templeton 1997, p. 230), and beauty are not the only aspects that unite Hedda and Zohara. The remark made about Hedda by Elizabeth Robbins (one of the first actors who took on this role in the English speaking world) is applicable equally to Zohara: she has 'a 
strong need to put some meaning into her life, even at the cost of borrowing it, or stealing the meaning out of someone else's' (Templeton 1997, pp. 231-32).

Moi notes that in Hedda Gabler, unlike earlier plays: 'the everyday is no longer potentially redemptive; it [is] ... a petty and banal sphere of routinized, conventional, and empty interactions' (Moi 2006, p. 318). The Zigzag Kid is full of attempts to transcend the everyday. Nonny is a policeman's son, yet for him, crimes and pranks are expressions of beauty and courage. Like Hedda's reckless practice shooting and her threats to burn her rival's hair, these actions hover on the threshold of lawfulness. When Nonny comes closer to crime or violence, he panics, partly because he senses that there is a part of him that is forever a 'fugitive' and a 'criminal' (Grossman 1998, p. 243).

Of course, a significant difference between Hedda and Zohara is their environment. Hedda is confined to the life of a nineteenth-century society wife, while Zohara is free to have adventures. Hanna Maron, who studied the role extensively and was inspired by the erotic tension in Munch's paintings (Snunit 1966), noted of the role: 'Before us is a person with potential, who because of her upbringing [and] environment ... was prevented from the possibility of communicating with others' (Bar-Kadma 1966). However, environment is not the only factor in Hedda's personality, and in fact, the reverberation of this character in Grossman's book illustrates this. Having transferred Hedda from nineteenth-century Norway to Israel and allowed her more freedom, Grossman has failed to prevent this character-type's tragic end.

Grossman lets Zohara enjoy everything that Hedda is denied. As a teenager in Mandatory Palestine, Zohara runs wild with the boys, ignores politics, and uses coarse language. Unlike Hedda, she does not lose her father. Instead, she sets off with her father on a two-year adventure, indulging in a life of crime. Still, when Zohara returns, just after the foundation of the state, and much like Hedda upon her return from her honeymoon, she is lost. 'I don't want more filthy lucre', she says to her father, 'and I don't want to swindle fools anymore. I just want to have some fun, to feel my heart beat, because life is so boring now that we're home, I could die of boredom here' (Grossman 1998, p. 251). These words parallel Hedda's complaints of being 'mortally bored' (Edmund and Archer 1911, p. 91), words that acquire their full meaning when she shoots herself in the last act. This sense of boredom might be more than just a reaction to her confining environment. 'Ibsen', asserted one Israeli reviewer, 'misses a full life, a life that is so full that it is impossible ... Hedda misses this kind of life and sacrifices her life on the altar of this longing' (Feuerstein 1966).

Zohara's boredom, or rather her longing for a life that is impossible, can be contextualized within the history of her country. Notably, her picaresque journey takes place precisely during the years that saw the outbreak of the Civil War in Mandatory Palestine followed by the expiration of the British mandate, the establishment of the State of Israel, the first Arab-Israeli war, the defeat of the Arab side, and the Nakba, which is the violent expulsion of over hundreds of thousands of Palestinians from their homes. None of these events make it into the novel. It is as if they happen off stage, influencing the main action without being acknowledged or seen. The violence, horror, and triumphalism of these years are hidden by the imagined story of a criminal and his daughter. Oz's novel can supplement some of the blanks in the story of Zohara's return to her country. He describes the years of austerity as the early 1950s came to be known:

Now that the years of euphoria were over, we were suddenly living in the 'morning after': grey, gloomy, damp, mean and petty. These were the years of blunt Okava razor blades, tasteless Ivory toothpaste, smelly Knesset cigarettes, ... cod-liver oil, ration books ... government work schemes, queues in the grocer's, larders built into kitchen walls, cheap sardines ... Arab infiltrators from the other side of the armistice line, the theatre companies, ... washing children's hair to get rid of the lice. (Oz 2005, p. 154)

To combat her boredom, Zohara decides on an act of daring: she climbs the roof of a diamond centre, performs a tune on her recorder for the policemen below and attempts an escape by walking across the arm of a crane to a nearby chocolate factory. The actions are as seemingly gratuitous as 
Hedda's burning of Løvborg's manuscript or her half-succesful attempt to turn the unfortunate author, who was once her would-be lover, to suicide. Zohara is pursued by Kobi, Nonny's future father, and she shoots him. Her motives, as interpreted by other characters in the novel, are reminiscent of Maron's explanation of the backstory in which Hedda threatens to shoot Løvborg: 'When he wanted to deepen their connection she was disgusted and threatened to kill him' (Bar-Kadma 1966). In Zohara's case, we hear that 'Maybe she felt that he was dangerous ... Not as a detective, but as a man. Maybe she could sense that he would play an important part in her life, and it threw her into a panic' (Grossman 1998, p. 257). Zohara's act, therefore, does not only echo Ibsen's play, it echoes the Israeli actor's interpretation of the play in 1966. With the story of Zohara's escapade, Grossman again lets his heroine have what Hedda is denied: she does not merely threaten to shoot her would-be lover, she actually shoots him, and after her release from prison, the two get married and set off for a remote farm near the Jordanian border. She gives birth to Nonny (whereas Hedda ends her pregnancy and her life in the final act) and she is happy for a short while; yet, all this proves to be a short reprieve from her problems.

Zohara's marriage to Kobi begins to fall apart because he is too fond of the radio broadcasts of football matches, a Friday newspaper, and an after-dinner bottle of malt-beer. Threatened by Kobi's encroaching domesticity, Zohara starts a serious fight when he buys a chintzy easy chair which reminds her of a similar piece of furniture owned by her former vulgar neighbour. In other words, Hedda, re-imagined in a different environment and in a love marriage, still suffers from an intolerance of vulgarity and the banality of everyday. The women's tragic deaths are not merely reflective of their similar personalities. Their suicides condemn their environments. Israel of the 1950s cannot contain Hedda any more than nineteenth-century Norway could. Indeed, reviews of the 1966 production show the critics' conservatism.

Israeli critics wished to improve Hedda instead of understanding her. The Jerusalem Post described Hedda as a 'self-centred destructive woman incapable of love' (Anonymous 1966). The left-wing Haaretz, articulated her problem as being unable 'to listen to [her] heart' (Gomzo 1966); an article in the right-wing Hayom claimed the play's message to be about people's need 'to learn how to match themselves to reality', while the pro-Soviet Kol-ha-Am condemned Hedda for being too emancipated and suggested that she should have been more like Thea. These reactions are not atypical; as Joan Templeton demonstrates, critics often deny Hedda her reality and the playwright his right for a subject by suggesting that Hedda is unrealistic or that her salvation lies in loving one or other of the male characters in the play 'simply because they are there' (Templeton 1997, p. 208). What such reactions show is an inability to transcend the very patriarchal structures against which Hedda rebels. Zohara's death, like Hedda's, transcends existing social structures.

The period shortly before Zohara's death is a difficult one. She keeps fighting with Kobi and often runs away to hide in the mountains or drink in Tel Aviv, only to have him collect her and bring her home. Her disappearance is believed by her parents to be either suicide or an accident: 'maybe she fell to her death from a cliff. Maybe she was murdered by infiltrators. The army made inquiries' (Grossman 1998, p. 284). The mystery of her death parallels Judge Brack's shout upon discovering that Hedda has killed herself: 'people don't do such things' (Edmund and Archer 1911, p. 224). Zohara is transgressive in that she ignores the facts of Israeli life in the 1950s, its contested borders, hostility with Jordan, 'infiltrators' or the Palestinian fedayeen, as they were known, and the political events that led to their actions. In Grossman's novel, the landscape where Zohara meets her death is not described in realistic detail. It is ostensibly a novel for children, and the story-within-a-story featuring Zohara is told by the bereaved parents to her young son. Underneath the fairy tale romanticism of this story, however, is the reality, such as described by $\mathrm{Oz}$ in the account of his nights in a kibbutz:

Beyond the barbed-wire fence lurked empty fields, deserted orchards, hills without a living soul, plantations abandoned to the night wind, ruins of Arab villages ... the night ... was still totally empty. And in this great emptiness infiltrators, fedayeen, crept though the heart of the night. And in this great emptiness ... drooling jackals roamed, whose lunatic, blood-curdling howls penetrated our sleep and froze our blood towards dawn. (Oz 2005, p. 497) 
Grossman's novel, in a way oddly like the autobiographical work by $\mathrm{Oz}$, centres on the son's impossible quest for the dead parent. The fictional Zohara cannot be brought back from the dead, and neither can Oz's mother Fania Klausner. A Tale of Love and Darkness, in reviving her Åse-like stories, reconstructing her life in the town of Rovno, and carefully recounting her final moments, confronts the impossibility of reversing or even fully understanding the death of a loved one, no matter how inspired the writing or meticulous the research. Grossman, similarly, sends his protagonist on a quest to uncover his mother's past. However, neither Zohara's nor Fania Klausner's suicide can be fully comprehended and brought out of the darkness that it engendered in the life of the narrators.

The only thing that can be done is the process symbolized in The Zigzag Kid by Nonny's wearing his mother's childhood clothes as a disguise. Through wearing her clothes and walking the path Zohara walked as a young girl, Nonny merges his mind with his late mother's until, in the endgame of the novel, he is able to guess the code of the safe where she has left him a present. Through this embodiment of Zohara, Nonny approximates what the novel admits as impossible-a true knowledge of the Other. The process is reminiscent of Grossman's description, in Writing in the Dark, of his ability, as an author, to subconsciously imagine the embodied life of his characters up to the point where he feels 'what it means to be another person' (Grossman 2006, p. 36). For Grossman, this ability to understand the Other through creative endeavour is crucially important precisely because he sees himself as writing in a 'disaster zone' (Grossman 2006, p. 47), which threatens to 'turn human beings into faceless one-dimensional creatures lacking volition' (Grossman 2006, p. 51). To understand Zohara and Hedda is to understand why people 'do such things'. In other words, it means confronting the violence of history and the complexity of the theatrical games that people play in order to survive and that often kill them.

\section{Conclusion: Ibsen and Israeli Modernism}

Having examined the possible meanings of Oz's and Grossman's allusions to Ibsen in the context of Ibsen's reception in Israel, I would like to address the following question: Why does it matter that $\mathrm{Oz}$ and Grossman mention Ibsen? After all, these allusions occupy a barely significant space on the pages of their works. Furthermore, what are the possible applications of the method adopted here for the study of modernism?

Firstly, it is worth mentioning that the present study deals with isolated instances of a larger phenomenon. There were many Ibsen productions in Hebrew, both before and after the foundation of the State of Israel; the catalogue of the Israeli Centre for the Documentation of the Performing Arts lists 47 files containing production materials of Ibsen's plays in Hebrew. In addition, there are reviews in the newspapers, and multiple articles in Hebrew periodicals. There are also multiple translations of the major plays (the National Library of Israel contains three different translations of Hedda Gabler and Peer Gynt). In other words, if one wished to apply D'Amico's six points to the study of Ibsen's reception to Israel, one would find a rich body of material. The seventh point proposed in this article refers to the allusions and echoes in fiction and drama. While it is difficult to estimate the number of these textual details across the corpus of Israeli literature, it is likely that further research in this direction should yield more results; several prominent Israeli writers, including Max Brod and Ephraim Kishon wrote reviews of Ibsen's plays, and there are some early articles on the connections between Nathan Alterman and Ibsen (Yerushalmi 1976). Moreover, the Hebrew Ibsen should be studied (as has been done by Freddie Rokem) in conjunction the records of the productions of his plays in the Palestinian theatres as well as the corpus of Arabic translations of Ibsen's works.

However, while Ibsen's presence on the Israeli stage was considerable, his plays are not likely to have been the agents of change. The first Hebrew performance in Mandatory Palestine took place in 1905 (Rokem 2011, p. 131), only a year before the playwright's death, and long after the European and even the belated British controversies over A Doll's House and Ghosts. Secularisation, feminism, and anti-idealism were central issues in the Israeli society throughout the twentieth century, but it is unlikely that their development was impacted by Ibsen's productions. Rather we are likely to find, as 
in the case of this article, that Ibsen's plays provided sites for the audiences and critics to engage with these issues as reflected through Ibsen.

What can be gained from the study of Hebrew and Israeli engagements with Ibsen (and indeed other modernist authors in translation), however, is more important than a measure of his impact. To examine Ibsen's reception in Israel means to study modernism from a new perspective, one that transcends temporal and national boundaries.

There have been several calls to redraw the map of our engagement with modernism, not least from Ibsen scholars and scholars of Jewish literatures. Thus, in examining the 'worlding' of Ibsen and his status in his native country, Narve Fulsås and Tore Rem challenge an outdated narrative of Ibsen's becoming modern through his emigration. Their work uncovers an array of networks, both domestic and foreign, that allowed the Norwegian author to become an acclaimed world classic (Fulsås and Rem 2018). Parallel-wise, Jewish literature can be seen as 'transnational and multilingual body of writing whose networks of linguistic and cultural exchange provide a clear counterpoint to the center-periphery model of global literary circulation' (Levy and Schachter 2015, p. 433). In addition, there have been calls to reexamine the temporal boundaries of modernism. Susan Friedman suggests that the traditional view of modernism as a period from 1890 to 1956 (Anselmo 2014) is the result of privileging the developments in Europe and the English-speaking world over a multitude of modernisms that occurred elsewhere. Indeed, if this traditional framework is accepted, then Ibsen is too early and Grossman and $\mathrm{Oz}$ are too late to be considered modernists. Instead, Friedman suggests seeing modernism as the 'expressive domain' of modernity, defined as a 'powerful vortex of historical conditions that coalesce to produce sharp ruptures from the past that range widely across various sectors of a given society' (Friedman 2006, p. 433). In this view of modernism, a comparative study of literary works from distant historical periods, revelas not a hierarchical chain of influence, but a conversation between equals.

This conversation, moreover, is two-sided. The later work may illuminate the earlier work's concerns, so that, for example, Grossman's Zohara extends the conversation about Hedda beyond the topic of the repressive aspects of her environment. Conversely, the earlier work may provide a historical counterpoint to the topic explored in the later work. In the case of Ibsen and the Israeli authors discussed here, this refers to Nationalism and Zionism. The ideology that gave birth to the State of Israel, and, by extension, to its literature, is, in the words of Sidra DeKoven Ezrahi, a 'modernist creation' (DeKoven Ezrahi 1998, p. 11). Zionism shares features with such cultural revivalist movements as, for instance, the Norwegian cultural revival, a movement which is the inspiration of Ibsen's early historical plays and which enabled Ibsen to receive a stipend to collect folklore. Ibsen's later exploration of myth making, identity, and their relation to national consciousness is relevant to Zionism precisely because of the centrality of myth to the movement. In Modernism and Zionism, David Ohana examines Zionism through the lens of what he calls 'mythical modernism', which he sees as the 'fundamental assumption of the ability of the individual to create a world in his own image, and in this way to establish a correlation between (modern) man and his (modern) world not through rational processes, but by means of a new myth' (Ohana 2012, p. 2). This is also one of the key themes of Peer Gynt. Looking at Israeli engagements with Ibsen means examining modernism from the opposite ends of the temporal spectrum.

Ibsen's Peer fantasizes about founding a country in the desert peopled by his offspring. When Goldberg has Peer refer to Gyntiana in terms evocative of the Zionist discourse, she draws attention to her position within the recently fulfilled fantasy and the concurrent frustrations of this situation. Her translation expands the reach of the play's exploration of myth making. The same can be said about the performance of the play. Peer Gynt, in spite of its critique of colonialism, has not been able to transcend the pull of orientalism (Helland 2009) and neither did the production. Its exotic portrayal of North Africa and the Middle East in Act 4 made no account for the geographical location of the production. Most reviewers did not have an issue with that, although one satirical piece described Peer being dressed as 'ole turki' [a new immigrant from Turkey] thus hinting at the generic orientalism of the production (Kishon 1952). 
A similar bringing together of historical perspectives occurs when Grossman mentions A Doll's House at the start of The Zigzag Kid. Gabi's raising her hand in the air is described though an allusion to a fictitious performance of $A$ Doll's House made by a fictional actress embodying two leading ladies of the Israeli theatre. Grossman does not specify whether this gesture, impressive enough to be remembered by a teenager, is made by Nora at the start of the play or at the moment of her radical rejection of her marriage and her society's ideals. Grossman's Gabi uses the gesture to signal her own rebellion. Not all children fit into the neat square shapes defined for them by the authorities, she argues, some children are 'zigzags' ${ }^{11}$ The rebellious zigzag and the shocking exit from a doll's house become intertwined.

The shape that gives the book its title is a symbol of deviance as an ethical and epistemological alternative to the established frameworks for examining the past. Nonny has to uncover his past in order to grow up into a responsible adult, but the past is no longer a convenient one-dimensional story, such as the Zionist narrative. Instead it is a zigzagging path across multiple conflicting narratives requiring equal degrees of imagination and integrity to navigate. Oz's autobiographical novel, though a more monumental undertaking, is a similar quest into the past. Like Grossman, Oz offers a multi-vocal, complex narrative, in place of the standard nationalist interpretation of the past. He presents this project as a way to understand his own place within the history of the conflict. For both authors, this quest into the past (undertaken also in their other works) has a redemptive function and is connected to their fight against the occupation and for the Palestinian civil rights. In playing with Ibsen, or rather in casually enlisting Ibsen's help in their exploration of the myths of Israeli nationhood and identity, Grossman and $\mathrm{Oz}$ do not merely nod to the past, they expose the intricate paths across physical and time-related borders which literary ideas take as they migrate, grow, and metamorphose.

Funding: This research was funded by NUI Galway College of Arts, Social Sciences, and Celtic Studies Research Support Scheme 2018.

Conflicts of Interest: The author declares no conflict of interest

\section{References}

Aisenberg, A. 1952. Hirhurim Sheleahar Hatzaga. Kiryat Ata: Haoved Hatzioni, pp. 274-75.

Anonymous. 1966. Theatre. Jerusalem Post, May 13.

Anselmo, Anna. 2014. Modernism. EDUCatt-Ente per il Diritto allo Studio Universitario dell'Università Cattolica. Available online: https://educatt.unicatt.it/ (accessed on 1 October 2018).

Archer William, and Charles Archer, transs. 1909, Peer Gynt. New York: Charles Scribner's Sons.

Bar-Kadma, Emmanuel. 1966. Malkha al HaKrashim. Yediot Ahronot, May 20.

Barthes, Ronald. 2013. The Death of the Author. In Modern Criticism and Theory: A Reader, 3rd ed. Edited by David Lodge and Nigel Wood. New York: Routledge.

D'Amico, Giuliano. 2014. Six Points for a Comparative Ibsen Reception History. Ibsen Studies 14: 4-37. [CrossRef] DeKoven Ezrahi, Sidra. 1998. Israel and Jewish writing: The next fifty years. Religion E Literature 30: 9-21.

Durbach, Errol. 1982. 'Ibsen the Romantic': Analogues of Paradise in the Later Plays. London and Basingstoke: Macmillan. Eshel, D. 1952. Per gint behadar bamato. Al Hamishmar, June 18.

Feuerstein, A. 1966. Hedda gabler beteatron hakameri. Hatzofe, June 17.

Finkel, Shimon. 1971. Be mavokh Tafkidi: Havayot Misednat Habima. Tel Aviv: Mifaley Tarbut ve Hahinuch.

Fish, Stanley Eugene. 1980. Is There a Text in this Class? The Authority of Interpretive Communities. Cambridge: Harvard University Press.

Friedman, Susan S. 2006. Periodizing modernism: Postcolonial modernities and the space/time borders of modernist studies. Modernism/Modernity 13: 425-43. [CrossRef]

Fromkin, David. 1989. A Peace to End All Peace: The Fall of the Ottoman Empire and the Creation of the Modern Middle East. New York: Avon Books.

11 The Hebrew title 'Yesh yeladim zigzag' literally means There are children who are zigzags or, slightly less awkwardly, 'some kids are zigzags'. 
Fulsås, Narve, and Tore Rem. 2018. Ibsen, Scandinavia and the Making of a World Drama. Cambridge: Cambridge University Press.

Goldberg, Leah. 1953. Per Gint. Reprinted in 1964. Tel Aviv: Davir.

Gomzo, Haim. 1966. Hedda Gabler be Kameri. Haaretz, May 20.

Gosse Edmund, and William Archer, transs. 1911, Hedda Gabler: The Master Builder. From Ibsen's Workshop. New York: Charles Scribner's Sons.

Grossman, David. 1991. See under: Love. Translated by Betsy Rosenberg. London: Picador.

Grossman, David. 1998. The Zigzag Kid. Translated by Betsy Rosenberg. London: Bloomsbury.

Grossman, David. 2006. Writing in the Dark. Translated by Jessica Cohen. London: Bloomsbury.

Unsigned. 1952. Habima: Per gint me'et henrik ibsen, ivrit lea goldberg, habamai sandro Malmquist. Haboker, June 6.

Hale, John K. 1989. Milton Playing with Ovid. Milton Studies 25: 3-19.

Hansen Anna, and Peter Hansen, transs. 1956, Per Giūnt. Genrik Ibsen. Leningrad and Moscow: Gosudarstvennoe izdatel'stvo Iskusstvo.

Helland, Frode. 2009. Empire and culture in Ibsen. Some notes on the dangers and ambiguities of interculturalism. Ibsen Studies 9: 136-59. [CrossRef]

Ibsen, Henrik. 1867. Peer Gynt. Historisk-Kritisk Utgave. Oslo: University of Oslo.

Israel, Sh. 1952. Per gint meanyen velo meza'az'ea. Sulam, July 13.

Jacobs, Adriana X. 2014. The Go-Betweens: Leah Goldberg, Yehuda Amichai, and the Figure of the Poet-Translator. In A Companion to Translation Studies. Edited by Sandra Bermann and Catherine Porter. London: Wiley Blackwell, pp. 479-91. [CrossRef]

Kishon, Ephraim. 1952. Aladar roe et per gint. Maariv, August 8.

Levy, Lital, and Allison Schachter. 2015. Jewish Literature/World Literature: Between the Local and the Transnational. PMLA 130: 92-109. [CrossRef]

Machacek, Gregory. 2007. Allusion. PMLA 122: 522-36. [CrossRef]

Marker, Frederick J., and Lise-Lone Marker. 1989. Ibsen's Lively Art: A Performance Study of the Major Plays. Cambridge: Cambridge University Press.

Mendelson-Maoz, Adia. 2010. Amos Oz's A Tale of Love and Darkness within the Framework of Immigration Narratives in Modern Hebrew Literature. Journal of Modern Jewish Studies 9: 71-87. [CrossRef]

Moi, Toril. 2006. Henrik Ibsen and the Birth of Modernism: Art, Theater, Philosophy. Oxford: Oxford University Press. Morgenstern Christian, trans. 1907. Peer Gynt. Henrik Ibsen. Volksausgabe in fünf Bänden. Berlin: S. Fischer, vol. 2, pp. 421-590. Available online: https://gutenberg.spiegel.de/buch/peer-gynt-1716/1 (accessed on 1 October 2018).

Ohana, David. 2012. Modernism and Zionism. Berlin: Springer.

Oz, Amos. 2005. A Tale of Love and Darkness. Translated by Nicholas de Lange. London: Vintage.

Rokem, Freddie. 1996. Hebrew Theater from 1889 to 1948. In Theater in Israel. Edited by Linda Ben-Zvi. Ann Arbor: University of Michigan Press, pp. 51-84.

Rokem, Freddie. 2011. Peer Gynt in Israel. In Global Ibsen: Performing Multiple Modernities. Edited by Erika Fischer-Lichte, Barbara Gronau and Christel Weiler. New York: Routledge, pp. 131-47.

Rubin, Adam. 2005. Hebrew Folklore and the Problem of Exile. Modern Judaism 25: 62-83. [CrossRef]

Ruppo Malone, Irina. 2010. Ibsen and the Irish Revival. Basingstoke: Palgrave.

Shean, Nava. 2010. To Be an Actress. Laham: Hamilton Books.

Snunit, Mikhal. 1966. Harbe Zman Halamti Lehatzig et Hedda. Hotam, May 24.

Templeton, J. 1997. Ibsen's Women. Cambridge: Cambridge University Press.

Yerushalmi, Yosef. 1976. Al Henrik Ibsen be-Ivrit/Bibliografia. [About Henrik Ibsen in Hebrew: A Bibliography]. Bama 69-70: 122-23.

Zusman, Ezra. 1952. Per Gint be habima. Davar, June 13.

(C) 2019 by the author. Licensee MDPI, Basel, Switzerland. This article is an open access article distributed under the terms and conditions of the Creative Commons Attribution (CC BY) license (http://creativecommons.org/licenses/by/4.0/). 